\title{
CONCEIVING TRANSFORMATION WITHOUT TRIUMPHALISM: JOACHIM OF FIORE AGAINST GIANNI VATTIMO
}

\author{
David Newheiser \\ Something happened to me as / was meditating on this book \\ something for which, relying on the gift of God, \\ I am made more bold to write.
}

Gianni Vattimo enthusiastically proclaims the advent of the postmodern, which he believes holds the prospect of transformation from an authoritarian past into a new age of freedom. ${ }^{1}$ Vattimo claims that the overcoming of metaphysics enables the recovery of Christian faith, albeit a faith now purged of literalism and hierarchy. In order to articulate this postmodern religiosity, Vattimo depends upon the medieval abbot Joachim of Fiore, harnessing Joachim's spiritual interpretation of scripture and his view of history as progress towards the age of the Spirit in support of his own vision for a Christianity without dogma. Vattimo writes, 'Joachim of Fiore offers us a model for living postmodern religious experience on the basis of the specific content of his teaching on the age of the Spirit and of his general theological tendency to understand salvation history as the story of the transformation in which the Scripture's meaning is spiritualized. ${ }^{2}$ Unfortunately, as I shall argue, he misconstrues Joachim on both counts.

In the tumultuous twelfth century Joachim predicted that the tribulations described in the Apocalypse of John would arrive imminently, followed by a period of unparalleled peace. By interpreting the biblical description of tribulation and renewal as historical in character, Joachim activates a revolutionary hope for transformation in time, one that went on to inspire his followers to proclaim the advent of Joachim's spiritual age. ${ }^{3}$ Vattimo thus stands in a long line of those which saw themselves as verging on a new era of freedom, but in this he shares an error common to Joachim's disciples and his most bitter detractors. Whereas Vattimo supposes that the Age of the Spirit replaces the ecclesial institutions that preceded it, Joachim is clear that they will persist; and while Vattimo 
supposes that Joachim's spiritual interpretation of scripture replaces literal readings, Joachim sees them as operating harmoniously together - a pattern of continuity in difference that is exemplified by the unity-in-distinction of the Trinitarian persons.

Whereas Vattimo's account of 'the new - postmodern - age of being'4 depends upon a momentous misreading of Joachim's texts, Joachim's account of the relationship between time and transformation offers a corrective to Vattimo's enthusiasm for the present moment. Under the force of his insistence that the future and the past remain intertwined, Joachim develops a vision of what the future might bring while admitting that, since the coming age remains unfulfilled, such suggestions remain uncertain. Against a triumphalist postmodernism that would proclaim the arrival of new liberty with respect to the constraints of the past, Joachim suggests that we may hope for a transformation of the present order that is nourished by its continuing connection with what preceded it.

\section{SECULARIZATION AND THE SPIRITUAL}

Vattimo characterizes the postmodern age as 'the epoch in which reality can no longer be conceived of as a structure solidly tied to a sole foundation. ${ }^{15}$ As Vattimo describes it, this situation arises philosophically from the denial of metaphysics found in Heidegger and Nietzsche, and it arises politically from the erosion of a Eurocentrism that privileged a particular history and culture at the expense of those it deemed primitive. ${ }^{6}$ In his view, the postmodern replaces totalitarian objectivism with the experience of freedom, which has consequences for philosophy and politics but for religion as well. After all, Vattimo observes that, if the belief in a metaphysical God is no longer tenable, neither is the firm assertion that there is no God at all, for the latter is just as metaphysical as the first insofar as it claims access to an absolute truth. Thus, he writes, 'Since God can no longer be upheld as an ultimate foundation, as the absolute metaphysical structure of the real, it is possible, once again, to believe in God. ${ }^{17}$

Vattimo claims that 'the history of Being as the destiny of weakening ${ }^{18}$ echoes the Christian account of the incarnation of Christ. Drawing upon Paul, Vattimo sees the incarnation as an act of selfemptying by which God turns things over to humans once and for all, and this kenosis finds its corollary in the process of secularization by which forms of faith that claim to be absolute fade in favor of a 
salutary weakness. Since secularization and the refusal of metaphysical foundations finds some support in Christian dogma, he suggests that it may be possible to articulate a pluralistic Christian faith; as he explains, 'If it is in the mode in which the weakening of Being realizes itself as the kenosis of God...secularization shall no longer be conceived of as abandonment of religion but as the paradoxical realization of Being's religious vocation. ${ }^{19}$ Christianity need not fear the postmodern situation, then, for the death of God that Nietzsche announced is an opportunity to develop a form of postmodern faith, ${ }^{10}$ one that 'has the look of a conjecture, a risky wager, and ultimately a loving acceptance, devotion, and pietas. ${ }^{11}$

Vattimo claims that postmodern secularization represents an opportunity for Christian faith because Christianity is in fact its source. He writes, 'Christianity's vocation consists in deepening its own physiognomy as source and condition for the possibility of secularity. ${ }^{12}$ Vattimo's postmodern faith attempts to fulfill Christianity's calling in the recognition that secularization develops on the Christian doctrine of the incarnation. He explains, 'Jesus' incarnation (the kenosis, the self-lowering of God)...is already indeed an archetypical occurrence of secularization, ${ }^{13}$ and he goes so far as to describe secularization as 'an interpretive application of the biblical message that situates it beyond the strictly sacramental, sacral, or ecclesial realm. ${ }^{14}$ Secularization thus takes the form of a particular mode of biblical interpretation, one that follows Jesus in embracing 'the destiny of weakening' by shifting from the level of power and politics to human charity. Vattimo takes this weakening as emblematic of 'secularization as "spiritual" interpretation, ${ }^{15}$ and he sees Joachim of Fiore as its progenitor.

Vattimo mentions Joachim at several points across his work, usually as a Christian alternative to the authoritarian dogmatism that he takes to characterize institutional Christianity, ${ }^{16}$ but in After Christianity Joachim assumes a more central role. ${ }^{17}$ Vattimo admits that 'the signs of the approaching third age, which today we call the end of metaphysics, are obviously not the same ones observed by Joachim,' but he concludes that 'Joachim's text can still be our guide because of the general meaning of the age of spirit. ${ }^{18}$ Although Vattimo's philosophical sources are distant from Joachim on the level of content, he suggests that they are consonant on the level of form; indeed, he goes so far as to suggest that postmetaphysical moderns are developing upon Joachim's heritage. He writes, 'To understand modernity as secularization, namely as the inner and "logical" development of the Judeo-Christian 
revelation...means to read the signs of the times, in the spirit of Joachim of Fiore. ${ }^{19}$ Joachim's account of the age of Spirit involves a form of attention to historical signs that provides Vattimo with the means to identify the Christian roots of secularization, and Vattimo's very interpretation of history is an example of the spiritual interpretation that Joachim develops. Vattimo's vision of postmodern faith thus leans heavily on a certain account of Joachim's legacy.

\section{THE STATUS OF INSTITUTIONS}

On the face of it, Vattimo's appeal to Joachim's theology of history has a sort of intuitive force. Joachim divides history into three status (or 'states'): The first, which pertained in particular to God the Father, 'was in the time of the Law when the people of the Lord served like a little child for a time,' ${ }^{20}$ while the second, the era of the Son, 'was under the Gospel and remains until the present with freedom in comparison to the past but not with freedom in comparison to the future. ${ }^{12}$ The third, however, 'will come toward the end of the world, no longer under the veil of the letter, but in the full freedom of the Spirit when...those who will teach many about justice will be like the splendor of the firmament and like the stars forever. ${ }^{122}$ Since history here progresses from servitude to freedom, many commentators have concluded that Joachim envisioned the dissolution of the prevailing social order, ${ }^{23}$ and Vattimo agrees.

Although Joachim and Vattimo clearly differ in their construal of the details of this third age, they might seem to concur in their treatment of the relation between the past and future, as Vattimo claims. He writes: 'No longer servants but friends; no longer awe or faith but charity; and perhaps also not action but contemplation. We could dare to think of the long process of secularization that separates us from the historical epoch of the abbot from Calabria as the realization of the conditions that are bringing us closer to the advent of the third age. ${ }^{24}$ However, while Vattimo is correct to claim that, for Joachim, 'the spirit breathes wherever it wants; its kingdom is one of freedom, ' he is wrong to conclude that 'one cannot establish definitive limits to it without reducing the spirit to the letter. ${ }^{25}$ On the contrary, Joachim is clear that the freedom of the Spirit will not displace existing institutions.

On the one hand, Joachim's view of historical development does destabilize prevailing political and religious configurations. In his discussion of the three status he takes up Paul's words as his own: ' "Now we know in part and prophesy in part, but when that which is perfect has come that which is in 
part shall be done away with." '26 Because 'the second status was under the Gospel' ${ }^{27}$ while the third is yet to come, this invites the conclusion that the gospel itself is imperfect and subject to supersession. This interpretation is supported by his association of the third status with superior, spiritual men; while the age of the Father corresponds to the order of the married and the age of the Son to the clerics, the age of the Spirit corresponds to the monastic order, those who walk 'not according to the flesh but according to the spirit. ${ }^{28}$ This suggests that illuminated monks are better than clerics, and Joachim has furthermore been taken to suggest that the papacy itself will be abrogated. He writes that the 'partial perfection' of the papacy will be 'followed by universal perfection, ${ }^{29}$ that of the new monastic orders, and so he concludes, 'Nor will the pope be able to grieve over his own dissolution since he will know that he will remain in a better succession. ${ }^{130}$ In this light, Vattimo may claim that Joachim envisions 'no longer taking even the primacy of the pope literally. ${ }^{31}$

On the other hand, what Vattimo takes to indicate the dissolution of the papacy nevertheless allows 'a better succession;' likewise, Joachim is clear that the coming order of illuminated monks 'seems new but is not. ${ }^{12}$ Even at his most revolutionary, Joachim insists upon the continuity of history, which entails that, although structures will be subject to transformation, they will by no means be abrogated. After all, despite his reputation as a radical, Joachim frequently insists upon fidelity to the church. In his final testament he writes, 'By almighty God I ask my fellow abbots and priors and the other brothers who fear God...collect as quickly as possible all the works I have written...[and] present them to papal scrutiny. ${ }^{133}$ Far from representing a wildly independent revolutionary, he insists that 'I have always been prepared to hold what [papal authority] commanded or will command. I would defend no view of mine against its holy faith, fully believing what it believes, receiving its correction in morals as well as in doctrine. ${ }^{34}$ In fact, where some paint Joachim as a revolutionary operating at the fringes of the $12^{\text {th }}$ century church, he actually enjoyed the support of three consecutive popes ${ }^{35}$ and was summoned at one point by Pope Lucius III to illuminate a particularly obscure prophecy. ${ }^{36}$ Even in his speculation on the coming age he is clear that 'the sacred mysteries are rightly to be understood not wholly according to what they signify, but in accordance with the Catholic faith. ${ }^{137}$ Far from envisioning the dissolution of church structures, Joachim asserts that 'the gates of hell will not prevail against it. ${ }^{138}$ 
It is thus misleading for Vattimo to claim that, for Joachim, 'one cannot establish definitive limits to [the spirit] without reducing the spirit to the letter, ${ }^{139}$ for Joachim's account of the spiritual age is itself limited by his Catholic faith. However, on Joachim's terms this actually represents no constraint upon the spirit, for the second age (the age of the clerics) is attributed 'to the Son and the Holy Spirit in common. ${ }^{40}$ Rather than simply opposing the spirit to the age that preceded it, Joachim sees clerical structures themselves as the Spirit's work. Although Joachim suggests that the coming monastic orders will be more fully spiritual, he is careful to specify that 'one order designated by the predecessor and another by the successor does not bring about difference of faith but the proper character of the form of religious life. ${ }^{41}$ Although the passage is ambiguous, it seems that Joachim envisions a development in the life of the papacy and not the abolition of it. ${ }^{42}$ Indeed, if Bernard McGinn is right to suggest that the passage refers to Joachim's departure from the Cistercians, ${ }^{43}$ that would indicate that Joachim's own experience provides a model for his broader construal of history, allowing for continuity in difference, development and departure while retaining a continued fidelity to the past. Where Vattimo takes the age of the spirit to dissolve the structures that preceded it, Joachim sees them as intertwined in a continuous process of unfolding; where Vattimo triumphantly proclaims the autonomy of the new, Joachim finds the seeds of the future in the past and the present.

\section{DIVERGENT INTERPRETATIONS}

Vattimo's argument hinges in particular upon his appeal to Joachim's practice of spiritual interpretation, and here too the relation between the two authors depends upon the character of time and transformation. Joachim distinguishes between typological interpretation (which he calls concordia, the Latin for agreement or harmony) and allegoria (which includes five types of spiritual interpretation). For Joachim, concordia develops typological parallels between individual figures; in a characteristic example, he argues that Jacob and John the Baptist correspond to each other, despite their manifest differences, for both exercise a form of fatherhood. He writes, 'In Jacob the generation of the flesh has been confirmed since he was the carnal father of that people called Israel on account of their father's cognomen. In John the Baptist the generation of the spirit has been confirmed since he was the father in the spirit of that people called Christian. ${ }^{144}$ In generating the people of Israel through physical 
procreation, Jacob typifies John's generation (through the Spirit) of the Christian people; thus, the two are tightly linked while John remains, nonetheless, the realization of what Jacob imperfectly signified. In contrast, where concordia develops one-to-one parallels between the Old and New Testaments, allegoria interprets individuals as figures for broader categories, with particular concern for the unfolding history of salvation.

Joachim comments that '[the things] of the Old Testament refer more to the flesh, these of the New more to the spirit. ${ }^{145}$ Insofar as this method of interpretation allows for the spirit of the New be found in the flesh of the Old, Joachim might seem to share Vattimo's preference for the spiritual over the literal. After all, where Vattimo suggests that the literalism that he rejects would 'demand that biblical narratives be read as narratives of events that are "objectively" true, ${ }^{46}$ Joachim's attempt to link Jacob and John glosses over the historical situation in favor of what he takes to be their more basic unity. Yet, whereas such a reading might seem spiritual on the basis of Vattimo's vague contrast between spiritual interpretation and 'objective truth,' Joachim indicates clearly that interpretations in the mode of concordia 'are to be understood as parallels between the two Testaments, not as allegorical interpretations ${ }^{147}$ - which is to say, such a reading does not represent spiritual interpretation, per se. ${ }^{48}$ In fact, whereas Vattimo pits the spiritual against the literal without clarifying what either term means, Joachim gives spiritual interpretation a specific sense, one that is intimately tied to his understanding of the continuous development of history.

Joachim describes concordia as follows: 'According to this pattern, therefore, the persons of the one Testament and those of the other gaze into each others' faces. City and city, people and people, order and order, war and war, act in the same way, as well as any other things that are similarly drawn to each other by some affinity. ${ }^{199}$ In the conviction that these disparate elements are deeply connected, he ruminates at length upon the parallels between them. Extending his reflection on Jacob and John he explains, 'Just as the former people [i.e. the Jews] has been procreated by twelve patriarchs, the latter [i.e. the Christians] has been procreated by twelve apostles; but in the former that which has been born from flesh is flesh, while in the latter that which has been born from spirit is spirit. ${ }^{150}$ Jacob and John correspond to each other not merely because of their procreative function but also because each act of procreation relates to a pattern of twelve. Correspondence of this sort allows 
Joachim to demonstrate the continuity between the testaments, for each additional parallel corroborates his conviction that they exist in mutual harmony.

Ironically enough, although Joachim's concordia might seem spiritual on Vattimo's terms (if not on his own), this style of interpretation actually corresponds to that which Vattimo condemns as excessive literalism. Joachim writes, 'That understanding which is called concordia is similar to a highway that extends from a wasteland to a city. On the way it crosses valleys in which a traveler may wonder if he is on the right road and just as often passes over mountain heights from which he can see backward as well as forward and determine the right direction to take for the remainder of his journey by contemplating the road he has come. ${ }^{51}$ In the face of instability, it is by looking back that the path of salvation may be discerned, and this retrospective glance also illuminates what is to come. Because Joachim takes salvation history to be continuous - even if, as he suggests, the path is often obscure - he is convinced that a careful practice of reading may clarify the arc of this narrative. Joachim writes, 'Where the traveler is not able to illuminate either the journey he has completed or that which he ought still to finish - as customarily happens in the valleys - he drags himself more by faith and reason than by vision to the peaks' in order to understand where he has been and where he has arrived. These peaks represent those points of correspondence between the near past and the far past in scripture, as determined by concordia, which allows the traveler to plot his position in the present and to envision the future. After all, concordia describes not simply a form of (harmonizing) interpretation; it applies more basically to 'the concordia between the three status of the world. ${ }^{52}$ This harmony of history undergirds concordia as a style of interpretation, for it enables the retrospection and prospection in which such interpretation consists. But is precisely this continuity that Vattimo rejects.

Vattimo claims that Joachim's spiritual interpretation consisted in being 'oriented toward the inner conversion of the human being and toward contemplation,' and so he dismisses 'his too literal, insufficiently "spiritual" effort to forecast future events on the basis of complex symbolic deciphering of scriptural texts. ${ }^{153}$ For Joachim, however, attention to the future in terms of concordia cannot be opposed to the properly spiritual interpretations that fall under allegoria, for there is harmony here as well. Joachim insists that 'the spiritual understandings proceed from these historical words' ${ }^{154}$ - that is, from interpretations in the mode of concordia. What is more, contra Vattimo's vague characterization, 
Joachim is clear that allegoria extends beyond inward contemplation, often serving to clarify and develop points of doctrine. ${ }^{55}$ As an example of the latter Joachim says that 'Christ was conceived in the sixth month after Elisabeth conceived, because the church of the spiritual men was extraordinarily sterile until the sixth tempus of the second status ${ }^{156}$ - which is to say, Mary conceived Christ when she did in order to indicate that the church of spiritual men only began to flourish in the sixth period of the second age, towards the end of the age of the Son, in anticipation of the age of the Spirit. Because the upshot of this interpretation is to clarify the character of the church, such deciphering cannot be reduced to inwardness; on the contrary, it contributes to the project of clarifying Christian teaching. Nor could it supplant the 'objective' truth of the events described, for Joachim sees the literal and spiritual as serving complementary functions.

Joachim takes spiritual interpretation to contribute to the program of clarifying the course of history, and so it reinforces rather than displaces the clarifying work of concordia. In the space of a few pages he describes Jacob as a type both of John the Baptist (in the mode of concordia) and of the Holy Spirit (in the mode of allegoria); it thus runs counter to the spirit of Joachim's exegetical practice to opt for one in opposition to the other, as Vattimo does. Vattimo claims that 'if by now we are, at least in principle, in the age of spiritual interpretation...it seems clearly a contradiction to demand that biblical narratives be read...as prophecies of events that are "really" destined to take place in world history, ${ }^{157}$ but Joachim would reject both the premise and the conclusion. Where Vattimo claims in the name of a supposedly realized future that spiritual interpretation should simply replace the literal, Joachim envisions the two levels coexisting harmoniously.

\section{OBSCURE CONTINUITIES}

Vattimo admits at one point, 'I have a great difficulty understanding [Joachim], ${ }^{58}$ which by now ought to be clear. Vattimo appeals to 'the specific content of [Joachim's] teaching on the age of the spirit' and 'his general theological tendency to understand salvation history as the story of the transformation in which the Scripture's meaning is spiritualized, ${ }^{159}$ but he misconstrues Joachim on both counts. Where Vattimo opposes spiritual and literal interpretation, Joachim describes them as harmoniously functioning together, and where Vattimo assumes that the age of the spirit will abrogate what preceded 
it, Joachim sees the coming age as a transformation in the developing life of existing institutions. Vattimo's chief problem is that he fails to appreciate Joachim's insistence upon the unity of history, a unity that for Joachim is exemplified by the unity-in-diversity of the Triune God. But this unity makes all the difference, for it encompasses the literal and the spiritual, the past and the future, in the pluriform motion of salvation history.

Ironically enough, Vattimo's interpretation of Joachim accords with a longstanding line of interpretation pursued by Catholic ecclesiastics anxious about Joachim's orthodoxy. ${ }^{60}$ Vattimo's account of Joachim's theology of history echoes Joseph Ratzinger's suggestion that Joachim affirms 'the utopia of a Church that would depart from the Son and rise higher than him ${ }^{161}$ : where Ratzinger calls this 'the false element in Joachim, ${ }^{162}$ Vattimo valorizes it, but both authors perpetuate the tendency to conflate Joachim with his most radical supporters. Among the many enthusiasts who circulated wild proclamations in Joachim's name, Gerardo of Borgo San Donnino collected Joachim's work under the title The Eternal Gospel, which included an introduction by Gerardo that identified the collection with a new revelation that superseded the New Testament. Gerardo's work was quickly condemned, but even though Joachim would have rejected Gerardo's claims on his behalf, the two authors became closely associated, particularly by polemicists hostile to Joachim's legacy. Marjorie Reeves observes, 'It is not the devout biblical exegete who has lingered longest in the historical memory, but the imaginative, artistic apostle of a bold new spirit... The Abbot who submitted all his writings to the authority of the Pope has become transformed into a symbol of anarchy and revolutionary change. ${ }^{163}$ Nevertheless, despite such exaggerations, Joachim's theology of history is rooted in a Trinitarian theology that is deeply traditional. ${ }^{64}$

In an early attack, Thomas Aquinas claims that Joachim identifies the Old Testament epoch with the Father, the New Testament with the Son, and the coming age with the Spirit, and so Thomas objects that 'the Old Law corresponded not only to the Father, but also to the Son: because Christ was foreshadowed in the Old Law.... In like manner the New Law corresponds not only to Christ, but also to the Holy Ghost. ${ }^{165}$ From the perspective of Trinitarian theology, the point is reasonable enough, but the objection is undercut by the fact that Joachim's theology of history is shaped by his sense of the unity and diversity of the Trinitarian persons. Joachim writes, 'Because, in fact, there is one Father from whom 
the Son and the Holy Spirit proceed, one Spirit who proceeds simultaneously from the Father and the Son, two who proceed from one Father, the first status is correctly ascribed to the Father alone, the third to the Holy Spirit, the second to the Son and the Holy Spirit in common. ${ }^{166}$ Joachim thus agrees with Aquinas in ascribing the New Law to the Son and Spirit in common. In fact, although Joachim identifies an age characterized by the particular work of each person of the Trinity, he is careful to preserve their unity as well; he writes, 'I do not say this in order that one should believe that the kingdom or the work of one person should be divided from the kingdom or work of the two other persons - that would be abhorrent to the hearts of believers. ${ }^{167}$ Although distinctions may be drawn between the work of the persons in history, in each instance all three work together. ${ }^{68}$

This pattern is repeated across Joachim's writing: whereas he sometimes suggests that the status of the Spirit will surpass the status of the Son, he is clear that the one does not abrogate the other, for the Trinitarian persons continually cooperate. Joachim goes so far as to claim that 'the first status is ascribed to the Father, the second to the Son, the third to the Holy Spirit, although in another way of speaking the status of the world should be said to be one, the people of the elect one, and all things at the same time belonging to Father, Son, and Holy Spirit. ${ }^{69}$ In one sense there are three ages, three Trinitarian persons, and three classes of faithful people, but in another sense all these are united in the single activity of the one God. Accordingly, Joachim's account of the three status sometimes suggests that each consists in a distinct period of time, one following the other, an impression that is reinforced by his occasional use of tempora in the place of status, which explicitly denotes successive periods of time. However, when speaking of the threefold pattern of history, Joachim tends to use status instead of tempora - at one point correcting himself explicitly ${ }^{70}$ - which indicates that the states in question are interlocked with each other in an intertwining pattern of Trinitarian development.

This point is neatly illustrated in one of Joachim's figurae, a striking image which depicts the Trinity as a tree whose trunk rises in three successive circles (Figure 1)..$^{71}$ The first circle is that of the Father, who forms the root and source of the tree, and the second circle pertains to the Son, from whom (with the Father) the Spirit proceeds. The circles are formed by two intertwined trunks that represent the Jews and the Gentiles respectively. They flower more on the Jewish side in the circle of the Father and more on the Gentile side in the circle of the Son, but in the circle of the Spirit the two 
peoples are united at the tree's apex in a brilliant efflorescence of blue and red blooms. The tree's vertical orientation suggests that the age of the Spirit is somehow superior to the ages of the Father and the Son, and yet this development arises organically from what preceded it. ${ }^{72}$ From one perspective, there is a successive development, but final fulfillment here remains entirely dependent upon its continuity with the past. For Joachim, then, the future draws its vitality from the past even as the Father, Son, and Spirit flow through each other in a unified and continuous salvific history.

\section{BEYOND THE POSTMODERN}

Let there be no mistake: by situating the thousand-year reign of Christ within history, Joachim activates a revolutionary hope for transformation within time. Because he affirms that 'the third status will come toward the end of the world ${ }^{173}$ rather than after the world's end, he encourages expectation of the time when 'the life of the monks will be like rain watering the face of the earth in all perfection and in the justice of brotherly love, ${ }^{174}$ and his distinctive attempt to decipher the signs of the times encouraged his followers to identify which monks he meant. However, by enacting a rupture with the past in the name of the future, Joachim's disciples - from Gerardo of Borgo San Donnino in the thirteenth century to Gianni Vattimo in the twentieth - interrupt the anticipation he practiced by authoritatively identifying the new age. For Joachim, we cannot speak from the perspective of the future, for we remain entangled in the past. Caught, as we are, in the ambiguities of the present, the prospective glance is always imperfect, and so we should be wary of claims to represent the future's arrival. ${ }^{75}$ Instead, Joachim suggests that the past itself holds the prospect of unpredictable change.

Crucially, while Joachim's exegesis is characterized by the attempt to illuminate the path ahead, his suggestions concerning what is to come are inflected by uncertainty. Although he states that 'expectation of future events may be made certain by the unfolding of the present, ${ }^{176}$ he immediately adds, 'With this all said, our struggle is still not finished. ${ }^{177}$ Joachim resists the temptation to identify the arrival of the new age; instead, his glance is directed towards a future that remains obscure. '/ think that in that time the life of the monks will be like rain, ${ }^{18}$ he says without claiming an impossible certainty,

and he makes clear that the events told in Scripture 'will begin in a year or hour which God knows. ${ }^{179}$ By attempting to clarify the shape of the future through the interpretation of Scripture, Joachim 
inadvertently encouraged his followers to claim the future for themselves, but what they fail to appreciate is that Joachim insists that the future remains a matter of conjecture.

My argument here has little in common with the curmudgeonly complaint raised by scholars irked by modern appropriations of an ancient author. In fact, as I have argued elsewhere, ${ }^{80}$ I think it is legitimate to make use of texts in readings that are not bound by speculation concerning the author's context and intentions. Indeed, since reading is inevitably partial, the important thing is to be circumspect concerning the limits of one's reading and to be open to deeper understanding.$^{81}$ To his credit, Vattimo recognizes that he must bracket the content Joachim gives to the age of the Spirit in order to make use of its form. Nevertheless, his formal appeal to 'the general meaning of the age of spirit ${ }^{82}$ misconstrues the texts in question precisely at the points on which he depends upon them. This is significant because, whereas Vattimo reduces Joachim's spiritual interpretation to an empty abstraction and divorces future faith and ancient institutions in the face of Joachim's strenuous attempt to preserve their unity, it is on precisely these points that Joachim might complicate and enrich Vattimo's defense of faith in the present.

Joachim writes, 'Awakened from sleep about midnight, something happened to me as I was meditating on this book, something for which, relying on the gift of God, I am made more bold to write, ${ }^{183}$ and these words serve as a program for his interpretative practice. Rather than propounding new revelations, Joachim sought to illuminate what had already been given; he adopts the posture not of prophet but of interpreter. ${ }^{84}$ Yet where Joachim remains open to the surprise that may come in the context of laborious reading, Vattimo's partisan defense of a postmodern approach often seems closed to other perspectives. Much as Joachim's historical hope might lead us to envision profound transformation, we ought to be able to say 'something happened to me as I was meditating on this book, ${ }^{185}$ something truly surprising. Since Vattimo's reading of Joachim seems circumscribed by his preconceived hostility to the literal text of scripture and to the institutions of the Catholic church, it seems that his mind is decided at the outset. In contrast, by adopting the role of a reader rather than an authoritative prophet, Joachim offers a model of the earnest attempt to discern the fragile buds of the future in the tangled branches of the past, an effort that requires continual revision in relation to the unpredictable depth of texts. 
Joachim directs us beyond - beyond the present configuration of the world, beyond ideas and interpretations that are familiar, and beyond the comforting presumption to proclaim the realization of the new. Where Vattimo refers off-hand to 'the postmodern world, ${ }^{186}$ 'our postmodern experience, ${ }^{187}$ and 'the epoch in which we live today, which is rightly called postmodern, ${ }^{188}$ we might suspect that our world is somewhat more complicated, and we might hope that there is more yet to come. Where Vattimo stiffly claims that 'by now we are, at least in principle, in the age of spiritual interpretation rather than the age of literal interpretation of sacred Scripture,' 89 Joachim is clear that the future 'will be revealed after these things in the spiritual men ${ }^{190}$ - and so, because the revelation remains yet to come, he continues to await the future age of the Spirit. It is in this way that Joachim directs us beyond the postmodern, for he envisions a future that remains unassimilated to any realization on account of its continuing entanglement with the past.

\footnotetext{
${ }^{1}$ There are many postmodernisms, of course. Although Vattimo's postmodernism bears some affinities with the canonical account given by Jean-François Lyotard, Vattimo's work generally lacks the melancholy note that resounds in Lyotard's claim that 'this is a period of slackening' (Jean-François Lyotard, The Postmodern Condition [Minneapolis: University of Minnesota Press, 1984 ], p. 71. It is worth nothing that Vattimo also differs from Michel Foucault, Jacques Derrida, and Jean Baudrillard insofar as, although they are often taken to be paradigmatically postmodern, each of them disavows the label. Cf. Jacques Derrida, 'Derrida's Response to David Tracy,' in John D. Caputo and Michael J. Scanlon (eds.), God, the Gift, and Postmodernism (Bloomington: Indiana University Press, 1999), p. 181; Michel Foucault, 'Critical Theory/Intellectual History,' in Lawrence Kritzman (ed.), Politics, Philosophy, Culture: Interviews and Other Writings, 1977-1984 (Routledge: London, 1988), p. 34; and Jean Baudrillard, 'A Virtual State of Rupture,' in Mike Gane (ed.), Baudrillard Live: Selected Interviews (London: Routledge, 1993), p. 21.

${ }^{2}$ Gianni Vattimo, After Christianity (New York: Columbia University Press, 2002), p. 26

${ }^{3}$ Karl Löwith provocatively claims that 'there would be no American, no French, and no Russian revolutions and constitutions without the idea of progress and no idea of secular progress toward fulfillment without the original faith in a Kingdom of God' (Karl Löwith, Meaning in History [Chicago: The University of Chicago Press, 1949], p. 212), and he sees Joachim as the source of the hope that this Kingdom will arrive in history. Similarly, Jacob Taubes writes, 'Joachim's new calendar of history and his division of history into periods have to be understood as the context for all subsequent, apocalyptic waves of the modern age' (Jacob Taubes, Occidental Eschatology [Stanford: Stanford University Press, 2009], p. 82). Although these claims on behalf of Joachim's influence are exaggerated - other forms of periodization have been practiced, after all - they underscore the fact that his historical hope was unusual and significant.

${ }^{4}$ Vattimo, After Christianity, p. 137.

${ }^{5}$ Vattimo, ibid., p. 5.

${ }^{6}$ To these factors might be added Vattimo's discussion of the postmodern in an earlier work in connection with 'mass media' and 'generalized communication' (Gianni Vattimo, The Transparent Society[Baltimore: John Hopkins University Press, 1992]).

7 Vattimo, After Christianity, p. 6.

${ }^{8}$ Vattimo, ibid., p. 12.

${ }^{9}$ Vattimo, ibid., p. 24. This claim is questionable, of course; for an influential critique of such a deployment of 'secularization,' see Hans Blumenberg, The Legitimacy of the Modern Age (Cambridge: MIT Press, 1983). Vattimo hastily refutes Blumenberg in After Christianity, pp. 70-74, but the effect is not convincing.

${ }^{10}$ Harry Ausmus claims further that Nietzsche himself develops 'a secularized Joachimite eschatology' (Harry Ausmus, 'Nietzsche and Eschatology,' The Journal of Religion 58.4 [Oct. 1978], p. 349). Unfortunately, Ausmus draws rather vague parallels between the two thinkers, and this on the basis of the unjustified assertion that 'Joachim's triadic, eschatological, and historico-pantheistic view permeated much of nineteenth-century thought.'

${ }^{11}$ Vattimo, After Christianity, p. 8.

12 Vattimo, ibid., p. 98.

${ }^{13}$ Vattimo, ibid., p. 67.

${ }^{14}$ Vattimo, ibid., p. 45.

${ }^{15}$ Vattimo, ibid., p. 45.

${ }^{16}$ Thus, for instance, Gianni Vattimo, Beyond Interpretation: The meaning of Hermeneutics for Philosophy (Cambridge: Polity Press, 1997), p. 49.
} 
17 Thomas Guarino comments, 'Joachim serves as a legitimating prototype for Vattimo, signaling that his postmodern, postmetaphysical reinterpretation of Christianity is viable (and, indeed, deeply traditional)' (Thomas Guarino, Vattimo and Theology [London: Continuum, 2009], p.131).

${ }^{18}$ Vattimo, After Christianity, p. 31.

${ }^{19}$ Vattimo, ibid., p. 36.

20 Joachim of Fiore, 'Expositio in Apocalypsum,' in Bernard McGinn (ed.), Visions of the End: Apocalyptic Traditions in the Middle Ages (New York: Columbia University Press, 1979), p. 133.

${ }^{21}$ Joachim, 'ibid.,' p. 133.

22 Joachim, 'ibid.,' p. 134.

${ }^{23}$ See George La Piana: 'The problem of the Church, the Sacraments, and the Papacy in the new dispensation, destined to disappear because the ordo spiritualis would take their place, is the truly revolutionary doctrine of Joachim.... He gave to the monastic orders the right to consider themselves as the bearers of the spiritual Church, to affirm their independence from the Church of the Pope, nay, to consider it as the anti-Christ' (George La Piana, 'Joachim of Flora: A Critical Survey,' Speculum 7.2 [1932], p. 280).

${ }^{24}$ Vattimo, After Christianity, p. 31.

${ }^{25}$ Vattimo, ibid., p. 32.

${ }^{26}$ Joachim, 'Expositio,' pp. 133-4.

27 Joachim, 'ibid,' 'p. 133.

28 Joachim, 'ibid,' p. 134.

29 Joachim of Fiore, "Tractatus super quatuor Evangelia,' in McGinn (ed.), Visions of the End, p. 136.

30 Joachim, 'ibid.,' 135.

${ }^{31}$ Gianni Vattimo and John Caputo, After the death of God (New York: Columbia University Press, 2007), p. 100.

32 Joachim, 'Expositio,' 136.

33 Joachim, 'ibid.,' p. 141.

34 Joachim, 'ibid.,' p. 141.

${ }^{35}$ C.f. McGinn, Visions of the End, p. 126.

${ }^{36}$ C.f. Marjorie Reeves, The Influence of Prophecy in the Later Middle Ages: A Study in Joachimism (Oxford: Oxford University Press, 1969), p. 4.

37 Joachim of Fiore, 'Liber Concordia,' in Bernard McGinn (ed.), Apocalyptic Spirituality (New York: Paulist Press, 1979 ), p. 132.

38 Joachim, 'Expositio,' p. 141. Bernard McGinn comments, 'Popes had played no part in scriptural, patristic, or early medieval apocalyptic; but since inclusion in the final drama was a potent way of giving universal validation to changes in the structure of Christian society, the new position of the reformed papacy in the later Middle Ages seemed to cry out for such a conversation of status. Joachim was the first to provide it' (Bernard McGinn, 'Symbolism in the Thought of Joachim of Fiore,' in Ann Williams [ed.], Prophecy and Millenarianism: Essays in Honor of Marjorie Reeves [Harlow: Longman, 1980], p. 155).

${ }^{39}$ Vattimo, After Christianity, p. 32.

40 Joachim, 'Liber Concordia,' p. 130.

41 Joachim, 'Tractatus,' 135. Note, too, that Joachim's vision of 'The New Order of the People of God' retains a place for 'The Spiritual Father,' who may be the Pope and who is owed obedience (Joachim of Fiore, 'Liber Figurae,' in McGinn [ed.], Apocalyptic Spirituality, p. 144).

${ }^{42}$ Brett Whalen comments, 'For the most part, however, Joachim appeared to envision a continued role for the "spiritualized" papacy in the coming Sabbath age....even if he did believe that the Roman papacy of the spiritual age might look quite different from that of the current era' (Brett Whalen, Dominion of God: Christendom and Apocalypse in the Middle Ages [Cambridge, Mass.: Harvard University Press, 2009], pp. 119-20).

${ }^{43}$ McGinn, Visions of the End, p. 316.

44 Joachim, 'Liber Concordia,' p. 120.

45 Joachim, 'ibid.,' p. 122.

${ }^{46}$ Vattimo, After Christianity, pp. 28-9.

47 Joachim, 'Liber Concordia,' p. 120.

${ }^{48}$ Bernard McGinn comments, 'The difference between concordia and allegoria shows that Joachim's working out of exact historical parallels... between the Old and the New Testaments is not a part of the intellectus spiritualis, but rather belongs to the letter of Scripture' (Bernard McGinn, The Calabrian Abbot [New York: Macmillan Publishing Company, 1985], p. 130).

49 Joachim, 'Liber Concordia,' p. 122.

50 Joachim, 'ibid.,' p. 121.

51 Joachim, 'ibid.,' p. 123.

52 Joachim, 'ibid.,' p. 126.

${ }^{53}$ Vattimo, After Christianity, p. 44.

54 Joachim of Fiore, quoted in Delno West and Sandra Zimdars-Swartz, Joachim of Fiore: A Study in Spiritual Perception and History [Bloomington: Indiana University Press, 1983], p. 48. Elsewhere he writes, 'From the triple concordance of the letter [that is, from the three forms of concordia, corresponding to the three status of history] the twelve spiritual senses arise' (quoted in McGinn, Calabrian Abbot, p. 134).

${ }^{55}$ For this reason, Vattimo is wrong to claim that 'according to the line that...I propose to call Joachimist, the meaning of scripture in the age opened by the descent of the Holy Spirit becomes increasingly "spiritual" and thereby less bound to the rigor of dogmatic definitions and strict disciplinarian practice' (Vattimo, Beyond Interpretation, p. 50).

56 Joachim, 'Liber Concordia,' p. 123.

${ }^{57}$ Vattimo, After Christianity, p. 29.

${ }^{58}$ Vattimo, After the death of God, p. 100.

${ }^{59}$ Vattimo, After Christianity, p. 26. 
${ }^{60}$ In fact, one of the few sources Vattimo actually cites on Joachim is Henri de Lubac, who accuses Joachim of 'une transformation radicale' insofar as, in de Lubac's estimation, he 'rompait avec cette tradition unanime' (that is, with a Christocentric theology of history) (Henri de Lubac, La Postérité spirituelle de Joachim de Flore. Vol. 1, De Joachim à Schelling [Paris: Lethielleux, 1979], pp. 21-2).

${ }^{61}$ Joseph Ratzinger, The God of Jesus Christ (San Francisco: Ignatius Press, 2008), p. 108.

${ }^{62}$ Ratzinger, God of Jesus Christ, p. 108.

${ }^{63}$ Marjorie Reeves, Joachim of Fiore \& the Prophetic Future (Gloucestershire: Sutton, 1999), pp. 174-5.

${ }^{64}$ Bernard McGinn observes, 'What is distinctive about Joachim's theology of the Trinity is what might be called its archaism. Strongly scriptural and symbolic in outlook, displaying an adequate, though not profound, knowledge of the Fathers, it was in conscious reaction against the Scholastic application of logical categories and distinctions to theology' (Bernard McGinn, 'The Abbot and the Doctors: Scholastic Reactions to the Radical Eschatology of Joachim of Fiore,' Church History 40.1 [1971], p. 32). 65 Thomas Aquinas, Summa Theologica, trans. Fathers of the English Dominican Province, 1920, I-II, q. 106, a. 4.

66 Joachim, 'Liber Concordia,' p. 130.

67 Joachim, ibid.,' p. 130.

68 Joachim's approach resonates with Eugene Rogers's recent defence of 'a livelier appropriation of God-talk to the Spirit' against the tendency to underplay the Spirit's distinct work (Eugene Rogers, After the Spirit: A Constructive Pneumatology from Resources outside the Modern West [Grand Rapids: Eerdmans], 2005).

${ }^{69}$ Joachim, 'Expositio,' p. 134.

70 Joachim, 'Liber Concordia,' p. 124.

${ }^{71}$ Leone Tondelli, Marjorie Reeves, and Beatrice Hirsch-Reich, // Libro delle Figure dell'abate Gioachino da Fiore (Turin: Societa Editrice Internazionale, 1953), Vol. II, Plate XXII.

72 Jürgen Moltmann comments (though perhaps on a different image), 'This does not mean - nor would Joachim make such a claim, as his diagram of the Trinity in Liber Figuram proves - that there is a "future of the Spirit without Christ," as de Lubac claims. It certainly means, however, that there is no future of Christ without the Spirit' (Jürgen Moltmann, 'Christian Hope: Messianic Or Transcendent? A Theological Discussion With Joachim Of Fiore And Thomas Aquinas,' Horizons 12.2 [1985], p. 341).

73 Joachim, 'Expositio,' p. 134.

74 Joachim, 'ibid.,' p. 137.

75 There are several ways in which Joachim resonates, in my reading, with Kathryn Tanner's supple account of the Spirit's work for instance, in his conviction that the Spirit illuminates not merely through individual revelations but through the uncertain labor of interpretation, and in his insistence that the affirmation of the Spirit's work in history ought not entail the claim to identify the difference between the spiritual and the unspiritual. Tanner writes, 'Rather than try to short-circuit the messy course of human history in a rush for certainty, or narrowly channel history's pluriform course with a demand for control, we can therefore continue in such human processes....in the confidence that, even in our ignorance of it, God's Spirit is making its way in and through them' (Christ the Key [Cambridge: Cambridge University Press, 2010], p. 299).

76 Joachim, 'Liber Concordia,' p. 127.

77 Joachim, 'ibid.,' p. 127.

78 Joachim, 'Expositio,' p. 137. Emphasis added.

79 Joachim, 'Liber Concordia,' p. 135.

80 David Newheiser, "Time and the Responsibilities of Reading: Revisiting Derrida and Dionysius," in Scot Douglass and Morwenna Ludlow (eds.), Reading Then and Now: Postmodern Interpretations of the Church Fathers (London: T\&T Clark, 2011). ${ }^{81}$ By the same token, that there are dimensions of the roiling symbolism of Joachim's texts that escape the abstractions of the reading I have developed - a fact I take to characterize every reading, always and as such.

82 Vattimo, After Christianity, p. 31.

83 Joachim, 'Expositio,' p. 130.

${ }^{84}$ Marjorie Reeves comments, 'This is how most people thought of him: magnus propheta. But the interview with Adam of Persigny shows Joachim repudiating the title of prophet and claiming only the donum spiritualis intellectus. Again, this was interpreted in later legends as a sudden, miraculous gift of understanding to a miraculous man, but to Joachim it was illumination given at the end of arduous study and the faithful practice of psalmody, as laid down by the Benedictine Rule' (Reeves, Joachim of Fiore, p. 24).

85 Joachim, 'Expositio,' p. 130.

${ }^{86}$ Vattimo, After Christianity, p. 9.

${ }^{87}$ Vattimo, ibid., p. 6.

${ }^{88}$ Vattimo, ibid., p. 5.

${ }^{89}$ Vattimo, ibid., p. 29.

90 Joachim, 'Liber Concordia,' p. 127. 